brightest and gayest of the social gatherings, under the auspices of the Students' Representative Council and its president, Mr. Dickey. The uniforms of the officers of the warships at present in St. Andrews Bay, the bright robes of the foreign and British graduates, the varied hues of the ladies' attire, and the gowns of the students themselves lent a charming novelty to the picture.

Thus ended the stately celebration of the five-hundredth anniversary of the foundation of St. Andrews University, under the most cheerful of sunny skies, pure (but not "piercing" air), and amidst the unique academic surroundings of the place, which usually, and unfortunately, are wholly absent in those great populous centres where the universities spoken of by the rector will in future be. But the great stretches of pure sand, the expanse of the blue waters of the bay (on which the warships proudly ride), and the long lines of tidal rocks remind us that nowhere within the British dominions can the sciences of geology, botany, and zoology be studied under more inspiring or more favourable auspices than in the little city by "the cold North Sea." Be that as it may, one thing is certain, viz. that both guests and hosts vied with each other in making this celebration one of the most delightful and memorable gatherings it is possible to conceive.

W. C. M.

\section{EDWARD WHYMPER.}

I Edward Whymper, who died suddenly at Chamonix on Saturday last, September I6, we have lost one who was more than a most undaunted and successful climber of mountains. Born on April 27,1840 , the son of an artist and engraver on wood, he was brought up to the work and carried it to great perfection. He went to the Alps on a professional errand in 1860 and began his career as a climber. Next year he made the first ascent of the Pelvoux, and in 1864 vanquished its neighbour, the Ecrins, the highest summit of Dauphiné. Before that he had attacked the Matterhorn. How this was at last conquered, in $\mathrm{r}_{5}$, and of the tragedy of the return, when four lives were lost, it is needless to tell. In I867 he visited Greenland and attempted to penetrate the inland ice. It was a failure, though not from his fault. In 1872 he returned to do some surveying on the coast. In $1879-80$ he undertook his notable journey to the Ecuadorian Andes, during which he successfully ascended ten volcanic mountains, ranging from $I_{5}$, o0o feet to above 20 ,000 feet, most of them hitherto unclimbed, spent a night on the summit of Cotopaxi, and twice reached that of Chimborazo.

In later years Whymper made four or five exploratory expeditions in the Canadian Rockies and Selkirks. But he was more than a successful mountaineer: he was a keen observer of all natural phenomena. His two great and beautifully illustrated books, "Scrambles amongst the Alps" and "Travels amongst the Great Andes of the Equator," contain much of scientific value. $\mathrm{He}$ was a student of glaciers, and a keen critic of those who claimed for them great powers of erosion; a close observer of volcanic and other geological phenomena, and a collector who knew what was worth bringing. While at Disco Bav he obtained a fine series of fossil plants and of Eskimo relics. From the Andes he brought many specimens of rocks and other material, descriptions of which have been published, and himself wrote a paper on the aneroid barometer, besides devising a modification of the mercurial instrument for use on high mountains.

Whymper's latest books, "Chamonix and Mont

$$
\text { NO. } 2 \text { I } 86 \text {, VOL. } 87 \text { ] }
$$

Blanc," published in 1896 , and "Zermatt and the Matterhorn," which appeared in the following year, are admirable of their kind, and have met with great success. He was a fellow of the Royal Society of Edinburgh, had received the Patron's medal of the Royal Geographical Society, and been decorated with the Order of St. Maurice and St. Lazare, besides being an honorary member of foreign geographical societies and Alpine clubs. T. G. BONNEY.

\section{NOTES}

THE Government of the Commonwealth of Australia has promised to contribute $5000 l$. towards the expenses of the Mawson Antarctic Expedition, and the Victorian Government $6000 l$. This amount brings the contributions of the various Australian Governments to the sum of 22,00ol.

THE friends of the late Christian A. Herter have contributed to a memorial fund in recognition of his labours in promoting medical science. The fund, which amounts to $8000 l$., has been confided to the directors of The Journal of Biological Chemistry. The chief aim of the trust is to further the interests of that journal, which was founded by Herter.

According to the Revue Pratique de l'Electricité, a bronze statue has been erected at Poleymeux, in the Rhone Department, France, in memory of Ampère. The inventor is represented standing in an attitude of meditation, the right hand raised to the forehead, the left clenched. On the side is inscribed "La Science," suggestive of the subject of his meditation.

AN International Engineering Exhibition is to be held in April next at Baku, Russia, and will be open for six weeks. The exhibits will comprise internal-combustion engines, air-compressors, electrical apparatus, motor-cars, \&c. Particulars of the prospective arrangements may be obtained from the sole honorary representative in this country-Dr. P. Dvorkovitz, I Broad Street Place, E.C.

DR. R. KARSTEN, lecturer in comparative religion in the University of Helsingfors, has started on an expedition to Gran Chaco and Bolivia for the purpose of making investigations on the sociology and religion of various tribes of natives, some of whom are little known, while others have never been visited. He will be accompanied by his cousin, O. Lindholm.

M. G. Fayet, of the Paris Observatory, has been appointed astronomer at the Nice Observatory, in succession to M. Simonin.

Mr. Marconi has been elected president of the Junior Institution of Engineers in succession to $\mathrm{Sir} \mathrm{J}$. J. Thomson, F.R.S.

Mr. J. J. Nock has been appointed by the Secretary of State for the Colonies, on the recommendation of the Kew authorities, curator of the Hakgala Gardens, Ceylon.

THE meeting of the International Sanitary Conference to revise the provisions of the convention of 1903 for the prevention of the invasion and propagation of plague and cholera, is to take place in Paris on October to next.

$\Lambda$ CONFERENCE of members of the Museums Association and others interested is to take place in the Free Public Museums, Liverpool, on Wednesday, October 18 , the object being to discuss subjects of interest to those concerned in the work of museums.

Prof. Luigi Carnera, hitherto the director of the International Latitude stations at Carloforte and Oncativo, ras 